\title{
A Call to Boycott the 2022 Beijing Olympic Games and Establish Minimum Human Rights Standards for Olympic Hosts
}

MacIntosh Ross, Western University

Zumretay Arkin, World Uygur Congress

Frances Hui, We the HongKongers

Chemi Lhamo, Independent Activist Teng Biao, University of Chicago

Michael Heine, Western University

Ann Peel, Founding Chair, AthletesCAN; Former Vice-Chair, Athletics Canada; and Former Executive Director, Right to Play

Helen Jefferson Lenskyj, University of Toronto

Russell Field; University of Manitoba

Ornella Nzindukiyimana, St. Francis Xavier University

Laura Misener, Western University

Shakiba Oftadeh-Moghadam, Refugym

Charlene Weaving, St. Francis Xavier University

P. David Howe, Western University

Lhadon Tethong, Tibet Action Institute

Eli A. Wolff, Power of Sport Lab

Critical Commentary

Journal of Emerging Sport Studies

Volume 6, (2021): London, Ontario

All Rights Reserved, 2021: ISSN - 2562-3184 
I n awarding the 2022 Winter Olympic and Paralympic Games to Beijing, ${ }^{1}$ People's Republic of China (PRC), the International Olympic Committee (IOC) once again demonstrated a complete lack of concern for the Universal Declaration of Human Rights (UDHR), ignoring the well-being of Tibetans; Hong Kongers; Southern Mongolians; and Uyghurs, Kazakhs, Uzbeks, Kyrgyz, and other Turkic Muslims. The UDHR is the cornerstone of two binding international treaties that we argue all Olympic and Paralympic hosts should be party to: International Covenant on Civil and Political Rights (ICCPR) and International Covenant on Economic, Social and Cultural Rights (ICESCR). The PRC has never ratified the ICCPR and regularly violates the ICESCR. In this commentary, we highlight the numerous human rights violations occurring in the PRC in relation to the Olympic and Paralympic Games, illustrating that the 2008 Beijing Olympics and Paralympics not only failed to improve the human rights situation in the PRC, they dramatically worsened the plight of many ethnic groups living under the authoritarian rule of Communist Party of China (CPC).

The IOC has maintained, since the inception of the modern Olympic Games in the late-19th century, that sport should be politically neutral. Nevertheless, as protests over human rights abuses gathered force in the months leading up the 2008 Beijing Olympic and Paralympic Games, then-IOC President Jacques Rogge called on the Chinese government to live up to a "moral engagement" when it came to respecting human rights in their country. Despite Rogge claiming that the protests in 2008 were a "crisis" for the IOC, the organization stood by its decision to award its signature event to Beijing. ${ }^{2}$ That this was done as much for commercial reasons as sporting ones speaks to the hollowness of the neoliberal promise that economic engagements lead to democratic improvements.

Nevertheless, the IOC's own constitutional document, the Olympic Charter, insists that the fundamental principles of Olympism (a sort of guiding philosophy of the Olympic Movement) rejects "discrimination of any kind, such as race, colour, sex, sexual orientation, language, religion, political or other opinion, national or social origin, property, birth or other status," in favour of "mutual understanding ... friendship, solidarity and fair play." ${ }^{3}$ That the IOC refuses to apply these values means that it has once more awarded the Games to Beijing, allowing the PRC to use the event to "sportwash" their international reputation in the face of the abuses detailed below.

In the PRC, a disproportionate number of human rights abuses are unfolding in the Regional Autonomous Regions and Areas where Tibetan, Uyghur, and Mongolian cultural milieus face forceful and coercive integration. Yet, as legal scholars Maria Lundberg and Yong Zhou explain, "There are clear rules articulated by the Chinese Constitution which seem to provide a strong legal basis for minority nationalities to maintain their group identity and distinctive culture."4 These rules are now largely ignored. The following article is divided into four subsections, each dealing with human rights abuses against a different group within the PRC's population. They include: Tibetans; Uyghurs, Kazakhs, Uzbeks, Kyrgyz, and other Turkic Muslims; Southern Mongolians; and Hong Kongers.

Although our focus in this commentary is not primarily about human rights abuses against the majority Han Chinese population in the PRC, we want to acknowledge that no group, regardless of cultural background, is immune to CPC oppression. ${ }^{5}$ Han scholars and activists have stood up against CPC policies in the past, only to find themselves imprisoned, without proper legal representation, for exercising their freedoms of speech and expression, often by voicing their support for the very groups discussed in this paper. No one who resists CPC tyranny is safe. 
Journal of Emerging Sport Studies - A Call to Boycott the 2022 Beijing Olympic Games 3
On 2 November 2021, tennis star Peng Shuai reignited debates around the CPC's human rights record by accusing former PRC Vice Premier Zhang Gaoli of sexual assault on social media. The post was promptly censored, and Peng disappeared from public life, presumably detained by the CPC. The Women>s Tennis Association took a firm stand against the CPC's refusal to provide convincing evidence of Peng's freedom, pulling all future events from the PRC. ${ }^{6}$ The IOC, on the other hand, has accepted the CPC's dubious assurances that Peng is safe and free, vividly illustrating the organization's prioritization of profits over human rights. ${ }^{7}$ The plight of Peng Shuai, plus the ongoing concerns regarding the cultural genocide inflicted upon Turkic Muslims in Xinjiang, has prompted diplomatic boycotts by the United States of America, United Kingdom, New Zealand, Australia, and Canada. ${ }^{8}$ Through this paper we hope to encourage additional global action by further contextualizing the 2022 Beijing Olympic and Paralympic Games against the backdrop of human rights, including, but not limited to, the rights to physical integrity, liberty and security of the person, procedural fairness in law, individual liberty, nondiscrimination, self-determination, and basic civil liberties.

\section{"The Least Free Place in the World": The CPC Assault on Tibetans}

When the IOC awarded the 2008 Summer Olympic and Paralympic Games to Beijing, there was a hope, championed by then IOC president Jacques Rogge, that such a global spotlight would improve the CPC's treatment of Tibetans. When English language media refers to Tibet, they are typically referring to both the larger Tibetan Autonomous Region (TAR) and smaller Tibetan Autonomous Prefectures (TAPs) in Yunnan, Gansu, Sichuan, and Quinghai Provinces. In sum, the TAR and TAPs represent part of the traditional Tibetan provinces of Ü-Tsang, Amdo, and Kham. Beginning on March 10, 2008, protests spread across the Tibetan Plateau, marking the $49^{\text {th }}$ anniversary of the uprising against oppressive CPC rule and the flight of the Dalai Lama into exile. As of 2021, Freedom House - an American non-profit, non-governmental human rights organization - places Tibet and war-torn Syria in a tie for the least free place on the planet. ${ }^{10}$

In 1959, Mao Zedong used the so-called "People's Liberation Army" to crush the March 10 revolt, killing 12,000 Tibetans and imprisoning another 42,000. About 27,700 were eventually released following stints in one of the CPC's re-education camps, but another 10,091 died in custody. ${ }^{11}$ As Human Rights Watch explains, the 2008 protests occurred amidst "ever-more intrusive controls over religious and cultural activities, accelerated state-led economic development, and large-scale compulsory resettlement of farmers and nomads." ${ }^{12}$ In the aftermath of the violence IOC President Jacques Rogge evaded questions about China and human rights, all the while maintaining that a boycott was not the answer. Somehow, Rogge promised, the Olympics would still improve the human rights situation in the PRC. To quote Olympic scholar Helen Jefferson Lenskyj, "Olympic officials had either been duped or, more likely, didn't care."13

The Tibetan resentment that boiled over in 2008 was the result of decades of CPC abuse, including several measures that exacerbated human rights abuses in the 1990s and 2000s. By 1996, CPC paranoia about the Dalai Lama's political influence in the region was on an upswing. Initially, many monks and nuns were forced to take patriotic education programs, commonly dubbed "Love your country, love your religion," vilifying the spiritual leader and arguing that loyalty to the CPC must surpass devotion to one's religion. This patriotic training was later expanded to lay Tibetans whom the CPC felt were particularly susceptible to the Dalai Lama's teachings. ${ }^{14}$ 
The "Strike Hard" campaigns also attacked religious freedoms in Tibet. Initiated in the 1980s, the CPC's Strike Hard campaigns pursued the large-scale suppression of crime, but often extended to the suppression of religion, speech, and assembly. Although the CPC often framed the Strike Hard campaigns as a tool to identify and punish separatists in Tibet, most amounted to nothing less than a direct assault on Buddhism, resulting in the arrest or displacement of thousands of monks and nuns. ${ }^{15}$ Closer to the Olympic Games, the CPC perpetrated a massive relocation of Tibetan herders from rural parts of the TAR and TAPs in Gansu, Qinghai and Sichuan to urban areas, destroying the traditional livelihoods of hundreds of thousands of people. ${ }^{16}$

The CPC's violent crackdown on Tibetan protestors in 2008 had serious political ramifications. As Robert Barnett documents, the State's violence "cemented an international perception of China as authoritarian at a moment when it seemed about to step beyond that at the Beijing Olympics that August." ${ }^{17}$ After the protests had largely settled, the CPC set about suppressing information about what had happened. On 26 March 2008, for example, authorities arrested filmmaker Dhondup Wangchen for his part in the production of the documentary film Leaving Fear Behind. Dhondup interviewed Tibetans about their views of the PRC. ${ }^{18}$ Not only did the CPC arrest and convict Dhondup, they used cyber-attacks to identify his supporters. As Ronald Deibert and Rafal Rohozinski explain in the Journal of Democracy, "Reporters Without Borders unknowingly propagated a link to a malicious website posing as a Facebook petition to release the Tibetan activist Dhondup Wangchen. As with computer network attacks, targeted espionage and social-malware attacks are being developed not just by criminal groups and rogue actors, but also at the highest levels of government."19

The 2008 Beijing Olympic and Paralympic Games did nothing but worsen the CPC's abuse of human rights in Tibet. In its 2010 World Report, Human Rights Watch noted that the TAR and TAPs of Qinghai, Sichuan, Gansu, and Yunnan Provinces remained "saturated with troops." ${ }^{20}$ Beginning with the 2008 protests, the CPC arrests virtually anyone who tries to share information about human rights abuses in the TAR and TAPs. Numerous examples exist, but space permits only a representative sample. In 2012, monk Yonten Gyatso was arrested in the Tibetan and Qiang Autonomous Prefecture and sentenced to seven years in prison for sharing information about the self-immolation of nun Tenzin Wangmo, as well as information about the experiences of Tibetans since the violent CPC suppression of protests in $2008 .{ }^{21}$ In 2015, Tibetan blogger Druklo was arrested in the Huangnan Tibetan Autonomous Prefecture in Qinghai Province on charges related to inciting separatism. In 2016, he was sentenced to three years in prison. Druklo was not given access to legal representation. His crimes included criticizing the lack of religious freedoms, possession of Wang Lixiong's banned book Sky Burial: The Fate of Tibet, posting about talks between the Dalai Lama and the CPC on social media, and other offenses. $^{22}$

In post-Games Tibet, self-immolation has become a common form of protest. The very first selfimmolation in Tibet's history was conducted by the Monk Tapey in February 2009, during the Tibetan New Year, and just before the anniversary of the 10 March 1959 Uprising. This is typically a period when Tibetans expect protests and Chinese authorities impose even stiffer controls in anticipation of unrest. Tapey's selfimmolation was a result of Chinese authorities canceling prayers at his monastery in Ngaba. Including Tapey, a total of 157 Tibetans have self-immolated to protest the CPC's use of cultural genocide in their homeland, including ten in exile. ${ }^{23}$ 


\section{"A dystopian hellscape on a staggering scale in Xinjiang"24: Uyghurs, Kazakhs, Uzbeks, Kyrgyz, and the CCP Assault on Islam}

In the early 2000s, the CPC used the social panic sparked by the 9/11 attacks in the United States of America to reorient its suppression of Uyghurs, Kazakhs, Uzbeks, Kyrgyz, and other Turkic Muslims; the State rebranded separatists - which were often little more than political and religious activists - as terrorists. ${ }^{25}$ As an extension of these efforts, the CPC forced Imams to undergo patriotic (re)education. ${ }^{26}$ Yet, the early 2000 s saw very few acts of political or religious violence unfold in the XUAR. ${ }^{27}$ The CPC merely leveraged the rhetoric of the Global War on Terror, perfected in the United States of America, as an excuse to pursue the eradication of Islamic cultures in the XUAR. Indeed, as scholar Sean R. Roberts explains, the CPC's motivation for the surveillance and suppression of Uyghurs and other Turkic Muslims "has never been about eradicating a perceived 'terrorist threat' in the region," but rather "implementing cultural genocide."28 Today, the CPC continues to relentlessly target Muslims, interpreting the simplest missteps as so-called pre-crimes, worthy of detention via their infamous "extrajudicial mass internment program." 29

In 2009, chaos erupted in Shaoguan when a group of Han Chinese factory workers attacked their Uyghur colleagues in their dormitories in reaction to a false claim of sexual assault. At least two Uyghurs were killed, prompting a peaceful protest in the XUAR capital of Ürümqi. As the protest grew in size, police and military confronted the group and matters turned violent. ${ }^{30}$ From that point forward, the CPC framed sporadic violent incidents in the XUAR and elsewhere in China as justification for a cultural assault on Uyghurs and Turkic Muslims more broadly. ${ }^{31}$ Today, religious freedoms are virtually non-existent in the XUAR, where the CPC has limited worship to state-sanctioned mosques led by state-sanctioned clerics, all of whom must receive CPC political training. The $\mathrm{CPC}$ bars minors from even entering mosques. ${ }^{32}$

Another tactic the CPC has employed to crush Uyghur culture is the imprisonment of leading scholars. Dozens of professors have been detained or disappeared for their cultural and political beliefs, and now face the threat of a lengthy detention, torture, and even death. ${ }^{33}$ In 2014, Ilham Tohti, a professor in the faculty of economics at the Central Nationalities University, was sentenced to life in prison on the charge of separatism. ${ }^{34}$ No evidence was ever presented to his legal team. In 2017, multiple Uyghur academics were imprisoned without due process. Tashpolat Tiyip, a professor of geography and former president of Xinjiang University, was secretly tried for separatism and sentenced to death. ${ }^{35}$ Authorities sentenced religions scholar Hebibulla Tohti, who was a state-sanctioned cleric and faculty member at Xinjiang Islamic University, to a decade in prison. ${ }^{36}$ Rahile Dawut, a professor of Uyghur folklore and traditions at Xinjiang University, disappeared during a trip to Beijing and she is now imprisoned by the CPC. ${ }^{37}$ It seems that an entire book could be written on the CPC's assault on Uyghur intellectuals, but these examples sufficiently represent the norm.

In 2016 the CPC's Counter-Terrorism Law of the People's Republic of China (Counter-Terrorism Law) came into effect, initiating a new wave of government oppression in Xinjiang, legally enabling the political reeducation of hundreds of thousands of Uyghurs and other Turkic Muslims in isolated camps. On 1 November 2019, numerous UN experts, including nine Special Rapporteurs and two working groups dedicated to Human Rights, ${ }^{38}$ communicated the enormous scale of human rights violations the CPC perpetrates via the CounterTerrorism Law: 
The application of the Counter-Terrorism Law and related practices raises serious concerns regarding increasing practices of arbitrary detention, enforced disappearance, absence of judicial oversight and procedural safeguards and restrictions of the right to freedom of expression, the right to freedom of thought, conscience and religion, the right to freedom of peaceful assembly, the right to education and the right to freedom of movement within an increasingly securitized environment, particularly for designated minorities, notably Uyghurs and Tibetans. ${ }^{39}$

Unsurprisingly, the CPC initially denied the existence of the camps, only to reverse course, claiming that the facilities existed but were merely used for vocational education programs. ${ }^{40}$ According to scholar Adrian Zenz, it is now obvious that the CPC is "indiscriminately subjecting large swathes of the Muslim population to extensive extrajudicial indoctrination procedures." 41

The re-education camps are also noted as sites of sexual assault by guards against Uyghur women. Tursunay Ziawudun, who fled to the United States of America after nine months in one of the CPC's camps, told the BBC that "women were removed from the cells 'every night' and raped by one or more masked Chinese men. She said she was tortured and later gang-raped on three occasions, each time by two or three men." ${ }^{42}$ A Uyghur detainee named Gulbahar Jalilova also recounted torture and sexual assault, telling the New York Times that a guard exposed himself to her, demanding oral sex. ${ }^{43}$ Qelbinur Sidiq, an Uzbek woman who taught Chinese language skills in one such camp, corroborated accounts of the torture and sexual assault of Muslim women in the camps. In an interview with the BBC, Sidiq explained that there were "four kinds of electric shock...the chair, the glove, the helmet, and anal rape with a stick... The screams echoed throughout the building...I could hear them during lunch and sometimes when I was in class." 44 A Kazakh (and former Chinese national) physician and teacher named Sayragul Sauytbay, who also worked at a camp, told of guards gang raping women in full view of other detainees in hopes of coercing confessions. ${ }^{45}$

Reports of mandatory birth control have also come to light, with Gulnar Omirzakh, a Chinese-born Kazakh, recounting how she was forced to accept an intrauterine device (IUD) after having her third child in 2016, the state-imposed limit at the time. ${ }^{46}$ Qelbinur Sidiq has also shared her experiences with forced birth control and sterilization. The government required Sidiq to be fitted for an IUD in 2017, forcibly upholding the region's birth quotas. When she had it illegally removed due to discomfort and bleeding, she was forced to get a second IUD. Two years later, at age 50, Sidiq was forced to endure a sterilization operation. ${ }^{47}$

Beyond the walls of the re-education camps, the XUAR has been reduced to a security state. The $\mathrm{CPC}$ has drastically restricted freedom of religion, criminalizing "virtually all religious behavior and any consumption of religious information that was not explicitly promoted by the state." ${ }^{4}$ The CPC now approves official versions of the Qur'an for use in China. In 2017, the CPC seized versions of the Qur'an published prior to 2012, labelling such texts as "illegal religious items," claiming these older translations contained more extremist material. ${ }^{49}$

The heavy-handed CPC assault on Uyghurs as a whole, rather focusing on the small number violent individuals, makes little sense unless the goal is cultural genocide. As Joshua Tschantret explains, "the indiscriminate repression used by the CPC invariably ends up targeting the largely peaceful Uyghur population while eluding the very actors whose violence the CPC purportedly wants to punish." 50 Such broad assaults on 
Journal of Emerging Sport Studies - A Call to Boycott the 2022 Bejjing Olyma
the rights of Uyghurs only serve to fuel the flames of discontent for Muslims in Xinjiang.

\section{"Horrific days are now starting"51: The CCP Attack on Southern Mongolian Culture}

Southern Mongolians primarily live in the Inner Mongolia Autonomous Region (IMAR). They were traditionally herders but, beginning in the early 2000s, the CPC forced hundreds of thousands of Mongolians to relocate from the grasslands to urban centres, dramatically curtailing their way of life. ${ }^{52}$ Although the CPC's claims that herding has a negative environmental impact on the grasslands has some merit, the expansion of mining and other extractive industries in the IMAR raises questions about the sincerity of their environmentalist claim..$^{53}$ Resettlement, in any case, has additional cultural ramifications for Southern Mongolians. As geographers Debbie Dickinson and Michael Webber explain, politicians "recognise that culture and land use are related, but largely perceive the link as unimportant, subordinate to the pursuit of economic development." ${ }^{n 4}$

In his 2006 article for the Asia-Pacific Journal on Human Rights and the Law, Fernand de Varennes highlighted numerous CPC measures used to dismantle Southern Mongolian culture. As is also the case in the TAR and XUAR, the CPC pursues the Sinification of the Inner Mongolia Autonomous Region (IMAR) by incentivizing Han Chinese people's settlement. The use of the Mongolian language in education and politics is collapsing. Many jobs outright require proficiency in Mandarin, which the CPC effectively prevents Southern Mongolians from attaining through inadequate funding for schools in predominantly Mongolian areas. In order to survive, parents are now forced to sacrifice their own Mongolian language, and with it a portion of their cultural heritage, in order to find work and secure proper education for their children in Han dominant communities. ${ }^{55}$

In 2011, Southern Mongolians rose up in protest after Mergen, a herder, was run over by a Han driver near Shilinhot. Mergen and other herders were attempting to block coal trucks from "driving across fenced prairies in Xiwu." ${ }^{56}$ The herders' civil disobedience was a result of growing tensions between traditional Southern Mongolian herders and a coal industry responsible for severe damage to the region's grasslands. ${ }^{57}$ As Enghebatu Togochog, Director of the Southern Mongolian Human Rights Information Center, explained "There are increasing conflicts between herders and miners as the authorities open up more mines in the grasslands to meet their goal of turning Inner Mongolia into the nation's energy base." 58

Under President Xi Jinping, the cultural existence of Southern Mongolians is increasingly under threat. Xi's focus on economic expansion, at the expense of Southern Mongolian culture, is a major source of rights violations. Resistance is met with force. When farmers protested the killing of their sheep via pollution from the smelting industry in Zaruud Banner, numerous individuals were detained. Similar to the Tibetan cases mentioned above, at least one farmer was detained for sharing information about the poisoning, illustrating the lengths authorities will go to in order to manipulate public discourse and crush freedom of speech. ${ }^{59}$

Southern Mongolian intellectuals have also been detained and imprisoned. In 2019, historian Lhamjab A. Borjigin was sentenced to a year in prison on charges of separatism and sabotaging national unity after publishing a book titled China's Cultural Revolution. ${ }^{60}$ In 2020, the PRC escalated their assault on Southern Mongolian culture, introducing Mandarin-only education requirements, fueling protests across the IMAR. The CPC has reacted with undue force, illustrating their contempt for Southern Mongolians and their culture. Between August 
and October of 2020, the CPC detained between 8,000 and 10,000 such protestors, sparking new concerns about arbitrary detention and disappearances. ${ }^{61}$ These detentions included cultural leaders like poet Nasanulzei Hangin, who helped lead protestors in Shuluun-tsagaan Banner, and musician Ashidaa, who participated in protests in Ordos. ${ }^{62}$

The situation is dire. To quote anthropologist Yang Haiying, himself Southern Mongolian, "All of this talk about allowing Mongolians, Tibetans, and Uyghurs to integrate into the Chinese nation is really about assimilating them... The Chinese government is now unwilling even to allow them to co-exist." ${ }^{63}$

\section{"Full-Scale Assault on Democracy"64: The CPC and Hong Kong}

Ever since the handover of Hong Kong from Britain to the PRC, the proposed "One Country, Two Systems" rationale for governance has been under attack by Beijing. In 2014, the PRC's refusal to permit open elections in Hong Kong prompted the Umbrella Movement. Under 1990 Basic Law, the goal of the Legislative Council of Hong Kong was supposed to be universal suffrage. In 2014, the PRC attempted to bastardize the notion of universal suffrage, suggesting up to three candidates be selected by Hong Kong's Electoral Committee. Once the candidates were established, the people of Hong Kong could then vote. The candidate elected by the people would then need to be approved by the PRC. ${ }^{65}$ In essence, the PRC's version of democracy left the final say on the leadership of Hong Kong in the hands of the CPC, stripping away any semblance of democracy within the proposed system. Beijing's attempt to manipulate the democratic process in Hong Kong sparked the Umbrella Protests and was ultimately defeated by a vote of the Hong Kong Legislative Council. ${ }^{66}$

On 3 April 2019, Secretary for Security John Lee introduced the "Fugitive Offenders and Mutual Legal Assistance in Criminal Matters Legislation (Amendment) Bill 2019" to the Legislative Council for Hong Kong. The bill proposed to allow the extradition of those accused of crimes to foreign countries and the PRC. Many Hong Kongers considered the bill a backdoor for the PRC's political suppression of Hong Kongers and took to the streets in protest. The bill was formally withdrawn from consideration that October.

In June 2020, the PRC announced its intention to circumvent Hong Kong lawmakers to implement national security legislation itself, securing the very extradition powers so reviled by Hong Kongers in 2019. In July, the legislation became a reality. According to Hong Kong Chief Executive Carrie Lam, the law was intended to "prevent, curb and punish acts of secession, subversion of state power, terrorist activities, and collusion with foreign or external forces to endanger national security." 67 The law meant the end of numerous extradition treaties, with foreign countries fearing that individuals sent to Hong Kong could now be subjected to the PRC's draconian legal system. ${ }^{68}$ In 2021, the PRC's suppression of the freedoms of speech, assembly, and expression reached new heights in Hong Kong when a total of 55 activists were arrested in a clear attempt at State intimidation. As of now, over 50 civil organizations have suspended their Hong Kong operations due to the limitations on freedom of speech.

Multiple academics have faced political and professional intimidation for their roles in pro-democracy protests in Hong Kong. Law professor Benny Tai was convicted of creating a public nuisance and fired from his tenured position at University of Hong Kong. Shiu Ka-chun, another legal scholar, saw his contract 
go unrenewed by Hong Kong Baptist University. ${ }^{69}$ Chan Kin-man, a retired sociologist from the Chinese University of Hong Kong, served 11 months of his 16 month sentence for his own role in the protests. ${ }^{70}$

Reflecting on his dismissal, Benny Tai lamented that such action "marks the end of academic freedom in Hong Kong." 71

\section{Calls to Action}

The IOC awarded the 2022 Beijing Olympic and Paralympic Games in full knowledge of the human rights abuses unfolding across the Tibetan Plateau, Xinjiang, Southern Mongolia, and Hong Kong. Although the PRC has not ratified the ICCPR, it nonetheless represents the international norms of our time with regard to cultural and political rights. Thus, the PRC's violation of, at the very least, the rights to physical integrity, liberty and security of the person, procedural fairness in law, individual liberty, and non-discrimination - in contradiction to the ICCPR - represents grounds for an international boycott of the 2022 Olympic and Paralympic Games. The PRC is also clearly in violation of the ICESCR including, but not limited to, its refusal to provide for self-determination and to protect basic civil liberties. ${ }^{72}$ The CPC's continued refusal to allow UN observers unfettered access to examine human rights abuses raises alarms that simply must not be ignored. ${ }^{73}$

In light of the human rights abuses outlined in this article, we issue the following calls to action:

1) That nations of the world each engage in a full (all athletes and personnel) or diplomatic boycott of the 2022 Beijing Olympic and Paralympic Games.

2) That all sponsors withdraw support for the 2022 Beijing Olympic and Paralympic Games.

3) That all official 2022 Beijing Olympic and Paralympic broadcasters refuse to televise the Games.

4) That the IOC refrain from awarding hosting rights to nations that have not ratified both the ICCPR and ICESCR.

5) That the UN use its influence over the IOC to draft a Memorandum of Understanding regarding minimum human rights standards for Olympic and Paralympic hosts, through which the IOC also agrees to make each host's human rights assurances public. 


\section{Endnotes}

1 The IOC and the IPC signed an agreement for the first time in 2000. The current agreement runs until 2032. See, https://olympics.com/ioc/news/ioc-and-ipc-to-partner-until-2032. It is important for readers to understand that the balance of power clearly lies with the IOC. See, P. David Howe, 'Sleeping with an Elephant: the relationship between the International Olympic Committee and International Paralympic Committee," in Routledge Handbook of the Olympic and Paralympic Games. Eds. Dikaia Chatziefstathiou, Borja García, and Benoit Séguin (London: Routledge), 240-251.

2 Andrew Jacobs, "Olympic Official Calls Protests a 'Crisis,"” New York Times, 11 April 2008. https:// www.nytimes.com/2008/04/11/world/asia/11 china.html\#: : text $=$ The $\% 20$ president $\% 20$ of $\% 20$ the $\% 20$ Olympic $\% 20$ committee $\% 2 \mathrm{C} \% 20 \mathrm{Jacques} \% 20$ Rogge $\% 2 \mathrm{C}$,news $\% 20$ media $\% 20 \mathrm{with} \% 20$ greater $\% 20$ access $\% 20$ to $\% 20$ the $\% 20$ country

3 IOC, Olympic Charter. https://stillmed.olympic.org/media/Document\%20Library/OlympicOrg/General/ EN-Olympic-Charter.pdf

4 Maria Lundberg and Yong Zhou, "Regional National Autonomy under Challenge: Law, Practice and Recommendations," International Journal on Minority and Group Rights 16 (2009), 281.

5 See Human Rights Watch, "World Report 2020: China," https://www.hrw.org/world-report/2020/countrychapters/china-and-tibet\#

6 For Peng Shuai’s disappearance see, MacIntosh Ross and Biao Teng, "\#WhereisPengShuai: Totalitarianism, violence against women and an overdue Olympic boycott?," The Conversation, 25 November 2021. https://theconversation.com/whereispengshuai-totalitarianism-violence-against-women-and-an-overdueolympic-boycott-172261. For WTA's cancellation of future events in the PRC see, Owen Churchill, "WTA pulls tennis tournaments from China over Peng Shuai's 'silencing by Beijing' in wake of sexual abuse remarks," South China Morning Post, 2 December 2021. https://www.scmp.com/news/china/article/3158095/womens-tennisassociation-citing-beijings-silencing-peng-shuai-pulls?module=live\&pgtype=homepage

$7 \quad$ For the IOC's "silent diplomacy" see, Eddie Pells, "U.S. Olympic board member pushes quiet diplomacy in Peng Shuai case," CBC, 8 December 2021. https://www.cbc.ca/sports/tennis/usopc-peng-shuai-quietdiplomacy-1.6277816

8 For the United States of America, United Kingdom, Canada, and Australia, see, Reuters, "UN chief to attend Beijing Olympics amid diplomatic boycotts," Al Jazeera, 9 December 2021.

https://www.aljazeera.com/news/2021/12/9/un-chief-to-attend-beijing-olympics-amid-diplomatic-boycotts. For New Zealand, see, Associated Press, "China dismisses decision by UK, Canada to join diplomatic boycott of Olympics as 'farce,"” Los Angeles Times, 9 December 2021. https://www.latimes.com/world-nation/ story/2021-12-09/china-dismisses-uk-canada-olympic-boycott

9 "Tibet Ranked as the Least Free Place in the World," Free Tibet, 4 March 2021. https://freetibet.org/newsmedia/na/tibet-ranked-least-free-place-world. Free Tibet report based on rankings issued by Freedom House. See "Freedom in the World 2021: Tibet," N.D. https://freedomhouse.org/country/tibet/freedom-world/2021.

10 Freedom House, "Countries and Territories," https://freedomhouse.org/countries/freedom-world/ scores?sort=asc\&order $=$ Total $\% 20$ Score $\% 20$ and $\% 20$ Status

11 Xiaoyuan Liu, To the End of Revolution: The Chinese Communist Party and Tibet, 1949-1959 (New York: Columbia University Press, 2020), 250.

12 Human Rights Watch, World Report 2009 (New York: Human Rights Watch, 2009), 245. 
13 Helen Jefferson Lenskyj, "The Case Against the Olympic Games: The Buck Stops with the IOC," in The Palgrave Handbook of Olympic Studies, eds. Helen Jefferson Lenskyj and Stephen Wagg (New York: Palgrave Macmillan, 2012.

14 Peter Dziedzic, "Religion Under Fire: A Report and Policy Paper on Religious Freedom in Tibet," The Tibet Journal 38 no. 3-4 (2013), 94.

15 Ibid.

16 Human Rights Watch, World Report 2008 (New York: Human Rights Watch, 2008), 268; Human Rights Watch, World Report 2012 (New York: Human Rights Watch, 2012), 324.

17 Robert Barnett, "The Tibet Protests of Spring, 2008: Conflict between the Nation and the State," China Perspectives 3 (2009), 6 .

18 “Tibetan Filmmaker Jailed After Unfair Trial,” Amnesty International, 8 January 2010. https://www. amnesty.org/en/wp-content/uploads/2021/07/asa170022010en.pdf

19 Ronald Deibert, and Rafal Rohozinski. "Liberation vs. Control: The Future of Cyberspace," Journal of Democracy 21, no. 4 (2010): 43-57.

20 Human Rights Watch, World Report 2010 (New York: Human Rights Watch, 2010), 292.

21 "Buddhist monk sentenced to 7 years for spreading information about Tibet," Reporters Without Borders, 23 August 2012. https://rsf.org/en/news/buddhist-monk-sentenced-7-years-spreading-information-about-tibet

22 “Tibetan Imprisoned for 'Inciting Separatism,"” Amnesty International, 27 April 2016. https://www. amnesty.org/en/wp-content/uploads/2021/05/ASA1739082016ENGLISH.pdf. See also, Joshua Eaton, "In Tibet, Bloggers Post at Their Own Risk," Public Radio International, 20 May 2015. https://www.pri.org/ stories/2015-05-20/tibet-bloggers-post-their-own-risk; Roy Greenslade, "Tibetan blogger jailed for "endangering social stability," The Guardian, 23 February 2016. https://www.theguardian.com/media/greenslade/2016/feb/23/ tibetan-blogger-jailed-for-endangering-social-stability

23 International Campaign for Tibet, "Self-Immolation Fact Sheet," https://savetibet.org/tibetan-selfimmolations/

24 Agnès Callamard, Amnesty International's Secretary General, as quoted by, "China: Draconian repression of Muslims in Xinjiang amounts to crimes against humanity," Amnesty International, 10 June 2021. https://www.amnesty.org/en/latest/press-release/2021/06/china-draconian-repression-of-muslims-in-xinjiangamounts-to-crimes-against-humanity/\#: :text=Uyghurs $\% 2 \mathrm{C} \% 20 \mathrm{Kazakhs} \% 20 \mathrm{and} \% 20 \mathrm{other} \% 20 \mathrm{predominantly} \%$ 20Muslim $\% 20$ ethnic $\% 20$ minorities, it $\% 20$ launched $\% 20 \mathrm{a} \% 20$ new $\% 20$ report $\% 20$ and $\% 20$ campaign $\% 20$ today.

25 Sean R. Roberts, The War on the Uyghurs: China's International Campaign Against a Muslim Minority (Princeton, NJ: Princeton University Press, 2020), 134.

26 Michael Dillon, China in the Age of Xi Jinping (New York: Routledge, 2021), 255.

27 For the relative absence of violence in the XUAR during the early 2000s, See, Roberts, The War on the Uyghurs, 135; James A. Millward, "Introduction: Does the 2009 Urumchi violence mark a turning point?," Central Asian Survey 28, no. 4 (2009), 348; Gardner Bovingdon, The Uyghurs : Strangers in Their Own Land (New York : Columbia University Press, 2010), 106. 
28 Roberts, The War on the Uyghurs, 237. As Darren Byler had shown, Hui Muslims are also subjected to increased surveillance and detention in Xinjiang. See, Darren Byler, In the Camps: China's High-Tech Penal Colony (New York: Columbia Global Reports, 2021), 26-37.

Darren Byler, In the Camps, 18.

30 Angel Ryono and Matthew Galway, "Xinjiang under China: reflections on the multiple dimensions of the 2009 Urumqi uprising," Asian Ethnicity 16, no. 2 (2015), 235-236.

$31 \quad$ As Roberts explains, "none of these developments suggested that there was any organized 'terrorist threat' within China's Uyghur population, let alone one that was connected to TIP [Turkistan Islamic Party] or any other international jihadist group. Instead, almost all of the incidents appeared to have their own local peculiarities that informed their motivations and intentions." See, Roberts, The War on the Uyghurs, 163.

32 Bovingdon, The Uyghurs, 71.

33 See, "China: Veteran democracy activist Yang Tongyan dies while on medical parole," Amnesty International, 8 November 2017. https://www.amnesty.org/en/latest/press-release/2017/11/china-democracyactivist-yang-tongyan-dies/; "China: Human rights defenders given long jail terms, tortured - UN expert," United Nations Office of the High Commissioner, 28 June 2021. https://www.ohchr.org/en/NewsEvents/Pages/ DisplayNews.aspx? NewsID $=27221 \&$ LangID $=\mathrm{E}$

34 Ebby Abramson and Dolunay Bulut, "Endangered Scholars Worldwide," Social Research 84, no. 3 (2017), viii.

35 Ibid, ix.

36 "Xinjiang Authorities Sentence Uyghur Scholar to 10 Years in Prison," Radio Free Asia, 9 August 2017. https://www.rfa.org/english/news/uyghur/scholar-08092017151559.html. See also, Ebby Abramson and Dolunay Bulut, "Endangered Scholars Worldwide," Social Research 84, no. 3 (2017), viii.

37 Ebby Abramson and Dolunay Bulut, "Endangered Scholars Worldwide," Social Research 87, no. 3 (2020), ix.

38 These included: Fionnuala Ní Aoláin, Special Rapporteur on the promotion and protection of human rights and fundamental freedoms while countering terrorism; Leigh Toomey, Vice-Chair of the Working Group on Arbitrary Detention; Luciano Hazan, Chair-Rapporteur of the Working Group on Enforced or Involuntary Disappearances; Koumbou Boly Barry; Special Rapporteur on the right to education; David Kaye, Special Rapporteur on the promotion and protection of the right to freedom of opinion and expression; Clement Nyaletsossi Voule, Special Rapporteur on the rights to freedom of peaceful assembly and of association, Dainius Puras, Special Rapporteur on the right of everyone to the enjoyment of the highest attainable standard of physical and mental health; Michel Forst, Special Rapporteur on the situation of human rights defenders; Fernand de Varennes, Special Rapporteur on minority issues; Joseph Cannataci, Special Rapporteur on the right to privacy; Ahmed Shaheed, Special Rapporteur on freedom of religion or belief; Nils Melzer, Special Rapporteur on torture and other cruel, inhuman or degrading treatment or punishment.

39 Fionnuala Ní Aoláin, Leigh Toomey, Luciano Hazan, Koumbou Boly Barry, David Kaye, Dainius Puras, Michel Forst, Fernand de Varennes, Joseph Cannataci, Ahmed Shaheed, Nils Melzer, "Mandates of the Special Rapporteur on the promotion and protection of human rights and fundamental freedoms while countering terrorism; the Working Group on Arbitrary Detention; the Working Group on Enforced or Involuntary Disappearances; the Special Rapporteur on the right to education; the Special Rapporteur on the promotion and protection of the right to freedom of opinion and expression; the Special Rapporteur on the rights to freedom of peaceful assembly and of association; the Special Rapporteur on the right of everyone 
to the enjoyment of the highest attainable standard of physical and mental health; the Special Rapporteur on the situation of human rights defenders; the Special Rapporteur on minority issues; the Special Rapporteur on the right to privacy; the Special Rapporteur on freedom of religion or belief; and the Special Rapporteur on torture and other cruel, inhuman or degrading treatment or punishment," United Nations Office of the High Commissioner for Human Rights, 1 November 2019, OL CHN 18/2019. https://www.ohchr.org/Documents/ Issues/Terrorism/SR/OL_CHN_18_2019.pdf

40 Adrian Zenz, “"Thoroughly reforming them towards a healthy heart attitude': China's political reeducation campaign in Xinjiang," Central Asian Survey 38, no. 1 (2019), 102.

$41 \quad$ Ibid, 123.

42 Tursunay Ziawudun as quoted by Matthew Hill, David Campanale and Joel Gunter, "'Their Goal is to Destroy Everyone': Uighur Camp Detainees Allege Systematic Rape," BBC, 2 February 2021. https://www.bbc. $\underline{\text { com/news/world-asia-china-55794071 }}$

43 Amy Qin, "China Targets Muslim Women in Push to Suppress Births in Xinjiang,” New York Times, 10 May 2021. https://www.nytimes.com/2021/05/10/world/asia/china-xinjiang-women-births.html

44 Matthew Hill, David Campanale and Joel Gunter, “'Their goal is to destroy everyone’: Uighur camp detainees allege systematic rape,” BBC News, 2 February 2021. https://www.bbc.com/news/world-asia$\underline{\text { china-55794071 }}$

45 Ibid.

46 Joanne Smith Finley, "Why Scholars and Activists Increasingly Fear a Uyghur Genocide in Xinjiang," Journal of Genocide Research 23, no. 3 (2021), 354.

47 Emma Graham-Harrison and Lily Kuo, "Uighur Muslim teacher tells of forced sterilisation in Xinjiang," The Guardian, 4 September 2020. https://www.theguardian.com/world/2020/sep/04/muslimminority-teacher-50-tells-of-forced-sterilisation-in-xinjiang-china

48 Roberts, The War on the Uyghurs, 210.

49 Michael Dillon, Xinjiang in the Twenty-First Century: Islam, Ethnicity and Resistance (London: Routledge, 2018), 189;

50 Joshua Tschantret, "Repression, Opportunity, and Innovation: The Evolution of Terrorism in Xinjiang, China.” Terrorism and Political Violence 30, no. 4 (2018), 584.

51 Yang Haiying, as quoted by Gao Feng and Gigi Lee, "Mongolians in China Face 'Cultural Genocide' as Language, Culture Swept Aside: Group,” 25 March 2021. https://www.rfa.org/english/news/china/ genocide-03252021093922.html

52 Enghebatu Togochog, "Ecological Migration and Human Rights," China Rights Forum 4 (2006), 26. https:/www.hrichina.org/sites/default/files/PDFs/CRF.4.2006/CRF-2006-4_Ecological.pdf

53 For a strong overview of the environmental motivations for Southern Mongolian displacement see, Michael Dillon, China in the Age of Xi Jinping (New York: Routledge, 2021), 266-270. 
54 Debbie Dickinson and Michael Webber, "Environmental Resettlement and Development, on the Steppes of Inner Mongolia, PRC.” The Journal of Development Studies 43, no. 3 (2007), 555.

55 Fernand de Varennes, “Language Rights of Minorities and Increasing Tensions in the People's Republic of China," Asia-Pacific Journal on Human Rights and the Law 2 (2006), 9.

56 Jonathan Watts, “Herder's death deepens tensions in Inner Mongolia,” The Guardian, 27 May 2011. https:/www.theguardian.com/world/2011/may/27/tensions-herders-miners-inner-mongolia. See also, Nimrod Baranovitch, "The 2011 Protests in Inner Mongolia: An Ethno-environmental Perspective," China Quarterly 225 (2016), 214.

57 Nimrod Baranovitch, "The 2011 Protests in Inner Mongolia: An Ethno-environmental Perspective," China Quarterly 225 (2016), 214.

58 Enghebatu Togochog as quoted by Jonathan Watts, "Herder's death deepens tensions in Inner Mongolia," The Guardian, 27 May 2011. https:/www.theguardian.com/world/2011/may/27/tensions-herdersminers-inner-mongolia. For the boom in mining see, Guanghua Xu and JianGuo Wu, "Socio-ecological transformations of Inner Mongolia: A Sustainability Perspective,” Ecological Processes 5 (2016), 7.

59 Michael Dillon, China in the Age of Xi Jinping (New York: Routledge, 2021), 269.

60 He Ping, "Ethnic Mongolian Author Sentenced, Placed Under 'Community Correction' Order," Radio Free Asia, 16 September 2019.

61 "Thousands Held in Inner Mongolia As Crackdown on Language Protesters Continues," Asian News Monitor, 22 October 2020.

62 Qiao Long and Sun Cheng, "Thousands Held in Inner Mongolia As Crackdown on Language Protesters Continues," Radio Free Asia, 20 October 2020. https://www.rfa.org/english/news/china/ crackdown-10202020092816.html

63 Yang Haiying as quoted by Gao Feng and Gigi Lee, "Mongolians in China Face 'Cultural Genocide' as Language, Culture Swept Aside: Group,” Radio Free Asia, 25 March 2021. https://www.rfa.org/english/news/ china/genocide-03252021093922.html

64 Editorial Board, "China’s full-scale assault on democracy in Hong Kong demands a U.S. response — but a careful one,” Washington Post, 22 May 2020. https://www.washingtonpost.com/opinions/globalopinions/chinas-full-scale-assault-on-democracy-in-hong-kong-demands-a-us-response--but-a-carefulone/2020/05/22/5018cdc2-9c51-11ea-ac72-3841fcc9b35f_story.html

65 "Decision of the Standing Committee of the National People's Congress on Issues Relating to the Selection of the Chief Executive of the Hong Kong Special Administrative Region by Universal Suffrage and on the Method for Forming the Legislative Council of the Hong Kong Special Administrative Region in the Year 2016," Tenth Session of the Standing Committee of the Twelfth National People's Congress on 31 August 2014. http://www.2017.gov.hk/filemanager/template/en/doc/20140831b.pdf

66 For a useful overview of this period in Hong Kong's history, see, Dillon, China in the Age of Xi Jinping, 276-277. 
67 Government of the Hong Kong Special Administrative Region Press Release, Video Message by Chief Executive at United Nations Human Rights Council Meeting. 30 June 2020). https://www.info.gov.hk/ gia/general/202006/30/P2020063000655.htm [https://perma.cc/7XX4-Q5JW]

68 For international reaction to the National Security Law see, Simon N.M. Young, "Introductory Note: The Law of the People's Republic of China on Safeguarding National Security in the Hong Kong Special Administrative Region," International Legal Materials 60, no. 1 (2021), 3.

69 For the treatment of Benny Tai and Shiu Ka-chun see, Ebby Abramson and Dolunay Bulut, "Endangered Scholars Worldwide," Social Research 87, no. 3 (2020), xii.

70 Chris Lau, "Occupy co-founder Chan Kin-man has 'no regrets' over going to jail after early release from Hong Kong prison,” South China Morning Post, 14 March 2020. https://www.scmp.com/news/hong-kong/ politics/article/3075200/occupy-co-founder-chan-kin-man-has-no-regrets-over-going

71 Benny Tai, as quoted by Joyce Lau, "University of Hong Kong fires Occupy Central founder Benny Tai," Times Higher Education, 28 July 2020. https://www.timeshighereducation.com/news/university-hongkong-fires-occupy-central-founder-benny-tai

72 See, Part I, Article 1, and Part II, Article 2, International Covenant on Economic, Social and Cultural Rights, United Nation's General Assembly Resolution 2200A, 16 December 1966. https://www.ohchr.org/en/ professionalinterest/pages/cescr.aspx

73 Human Rights Watch, "World Report 2020: China,” https://www.hrw.org/world-report/2020/countrychapters/china-and-tibet\# 